\title{
Evaluasi Penerapan SIAKAD Politeknik Negeri Madiun Menggunakan Pendekatan TAM dan EUCS
}

\author{
Evaluation of SIAKAD Politeknik Negeri Madiun \\ Using TAM and EUCS Approach
}

\author{
Muhaji Bayu Suryawan*1, Prihandoko \\ ${ }^{1}$ S2 Teknik Informatika Universitas AMIKOM Yogyakarta, ${ }^{2}$ Universitas Gunadarma Jakarta \\ E-mail: *1 bayu.ms@gmail.com, ${ }^{2}$ pri@staff.gunadarma.ac.id
}

\begin{abstract}
Abstrak
Sistem Informasi Akademik (SIAKAD) merupakan sistem pendukung penyelenggaraan pendidikan, sehingga dalam proses pendidikan dapat menyediakan layanan informasi yang lebih baik kepada mahasiswanya. SIAKAD memiliki peran yang vital dalam mengatur segala hal yang berkaitan dengan penyelenggaraan kegiatan akademik, karena dalam sistem informasi akademik komponen-komponen yang ada dapat saling berinteraksi. Namun demikian penerapan SIAKAD memerlukan evaluasi, diantaranya terkait dengan tingkat penerimaan dan tingkat kepuasan pengguna sistem tersebut. Tujuan peneilitan ini mengevaluasi penggunaan SIAKAD pada Politeknik Negeri Madiun (PNM). Penelitian ini menggunakan model Technology Acceptance Model (TAM) untuk mengetahui tingkat persepsi penerimaan pengguna terhadap SIAKAD dan End-User Computing Satisfaction (EUCS) untuk mengetahui tingkat kepuasan pengguna terhadap SIAKAD PNM. Penelitian ini menggunakan data primer berupa kuisioner dan jurnal ilmiah, referensi buku sebagai data sekunder. Metode pengujian menggunakan uji validitas, reliabilitas, uji normalitas dan analisis regresi linear. Hasil penelitian ini menunjukan bahwa SIAKAD PNM dapat diterima oleh pengguna dilihat dari aspek persepsi kemudahan dan persepsi kemanfaatan baik secara individual maupun secara simultan. Sedangkan tingkat kepuasan pengguna secara simultan terpenuhi dari aspek content, accuracy, format, ease dan timeline, tetapi secara individual tidak terpenuhi dari aspek accuracy, format, dan timelines.
\end{abstract}

Kata Kunci - SIAKAD, Evaluasi, TAM, EUCS

\begin{abstract}
Academic Information System (SIAKAD) is a support system of education, so in the process of education, it can provide better information services to students. However, SIAKAD implementation requires evaluation, among others related to the level of acceptance and level of user satisfaction of the system. This study aims to evaluate the use of SIAKAD at the Politeknik Negeri Madiun (PNM). The method used in this research is Technology Acceptance Model (TAM) to know perception level of user acceptance toward SIAKAD and End-User Computing Satisfaction (EUCS) to know the level of user satisfaction toward SIAKAD PNM. This study uses primary data in the form of questionnaires. This study uses primary data and secondary data. Test method using validity test, reliability, normality test and linear regression analysis. The results of this study show that SIAKAD PNM can be accepted by the user seen from the perception of ease of use and perception of usefulness both individually and simultaneously. The level of users' satisfaction simultaneously is fulfilled by the aspects of content, accuracy, format, ease and timeline, but individually they are not fulfilled from aspects accuracy, format, and timelines.
\end{abstract}

Keywords — SIAKAD, Evaluation, TAM, EUCS 


\section{PENDAHULUAN}

Perkembangan Sistem Informasi dan Teknologi Informasi (SI/TI) yang sangat pesat pada saat ini, telah dianggap juga sebagai sumber daya yang sangat penting bagi organisasi (baik organisasi pemerintah maupun organisasi swasta) [1], yang tidak hanya berperan sebagai suatu dukungan semata, namun juga telah berperan sebagai key operational, high potential, peran strategis, dan dapat dimanfaatkan untuk mendukung efektivitas, efisiensi, dan produktivitas dalam organisasi [2]. Pada lingkungan perguruan tinggi, pemanfaatan teknologi informasi dan komunikasi dapat diwujudkan salah satunya dalam bentuk Sistem Informasi Akademik (SIAKAD). SIAKAD bertujuan untuk mendukung penyelenggaraan pendidikan, sehingga dalam proses pendidikan dapat disediakan layanan informasi yang lebih baik kepada mahasiswanya. Sistem informasi akademik merupakan sebuah sistem yang dibuat dan dikembangkan dalam rangka mengelola data-data serta penjadwalan kegiatan akademik sehingga memberikan kemudahan kepada pengguna dalam kegiatan akademik kampus baik dengan intranet maupun internet. Namun demikian penerapan sistem informasi akademik tetap memerlukan evaluasi, apakah sistem informasi dan teknologi tersebut dapat diterima oleh user dengan baik dan apakah pengguna sistem merasa puas dengan infomasi dan kinerja dari sistem tersebut.

Dari paparan diatas penulis ingin mengetahui sejauh mana tingkat keberhasilan penerapan SIAKAD PNM dalam menunjang proses akademik di lingkungan Politeknik Negeri madiun. Salah satu cara untuk mengetahui tingkat keberhasilan dalam penerapan teknologi informasi dapat diketahui dengan mengukur sejauh mana tingkat penerimaan dan kepuasan pengguna terhadap teknologi yang diterapkan tersebut. Beberapa penelitian telah dilakukan oleh para peneliti untuk mengevaluasi tingkat keberhasilan penerapan teknologi informasi dengan mengukur tingkat penerimaan dan kepuasan pengguna akhir dari sistem tersebut.

Prihantara Aditya, Winarno Wing Wahyu, Henderi, 2015, melakukan penelitian dengan menggunakan metode UTAUT untuk mengetahui pengaruh variabel UTAUT terhadap minat mahasiswa untuk melakukan akses ke dalam Sistem Informasi Kemahasiswaan di STKIP PGRI Pacitan dan memberikan rekomendasi perbaikan sistem kedepannya. Hasil penelitian ini adalah bahwa variabel performance expectancy, effort expectancy, hedonic motivation, behavioral intention dan facilitating condition berpengaruh signifikan positif. Variabel ini mampu mempengaruhi penerimaan sistem sebesar 92,7\% [3].

Arifah Fatimah Nur, Rosidi Abidarin, Al Fatta Hanif, 2014, melakukan penelitian untuk mengetahui dan mengukur tingkat kepuasan pengguna terhadap aplikasi Online Public Access Catalog (OPAC) pada Perpustakaan STMIK AMIKOM Yogyakarta. Dengan diagram Importance Performance Analysis (IPA) dipadukan dengan Indeks Kepuasan Pengguna (IKP) didasarkan pada indikator-indikator dari lima dimensi EUCS. Hasil penelitian menunjukkan pengguna OPAC Perpustakaan STMIK AMIKOM Yogyakarta cukup puas dengan hasil perhitungan IKP $78,01 \%[4]$.

Nursyanti dan Erlangga, 2013, melakukan penelitian dengan menerapkan model kepuasan pengguna akhir pada kepuasan kerja untuk mengevaluasi sistem informasi pendidikan tinggi (SIMPERTI) Universitas bandar lampung. Pengukuran kepuasan didasarkan pada dimensi EUCS dengan parameternya yaitu: content, accuracy, format, ease of use, topical, system speed, reliability. Hasil penelitian ini adalah setiap dimensi kepuasan EUCS tidak dipenuhi oleh SIMPERTI UBL, karena masih belum semua pengguna mau untuk menggunakan sistem tersebut. Namun demikina secara umum hasil review menunjukkan bahwa masih sedikit orang yang menggunakan simperti dimensi EUCS di UBL, merasa puas dan sisanya masih belum benar-benar puas [5].

Wulan, 2017, melakukan evaluasi tehadap penerimaan bio sistem online di kabupaten magelang, dalam penelitiannya digunakan pendekatan TAM, dimana metode ini digunakan untuk mengukur tingkat penerimaan pengguna terhadap sistem tersebut, dalam penelitannya, aspek kemudahan dan manfaat menjadi kunci keberhasilan penerapan teknologi informasi yang digambarkan dengan tinggkat penerimaan pengguna akhir terhadap sistem terebut [6]. 
Safitri, 2013, dalam penilitian ini dilakukan pengukuran kualitas dari sebuah website virtual class, dengan pendekatan model TAM, penelitian ini menunjukan bahwa variabel dalam TAM berpengaruh signifikan terhadap virtual class. Berdasarkan hasil analisa webqual variable usability, variable kualitas informasi, variabel kualitas interaksi dan variabel overall rata-rata responden setuju keseluruhan website virtual class bernilai baik [7].

Kemudian penelitan yang dilakukan oleh Feoh, Linawati, Ni Made Ary Esta Dewi Wirastuti, 2015, yaitu mengukur kepuasan pengguna terhadap fasilitas layanan pada situs web egov Pemerintah di Provinsi Bali, dengan model EUCS dan Customer Satisfaction Index (CSI). Diketahui bahwa hasil dari penelitian ini adalah indeks kepuasan pengguna situs web e-gov yang menempatkan situs web Kabupaten Klungkung (tertinggi) dan situs web e-gov Kabupaten Tabanan (terendah) [8].

M. Zamroni Uska, 2016, melakukan evaluasi SIAKAD STKIP Hamzanwandi Selong dengan menggunakan metode ERP succes model, dalam penelitianya bahwa kesuksesan SIAKAD diukur dari variabel kualitas informasi, kualitas sistem dan kualitas layanan. Dijelaskan bahwa ketiga variabel tersebut berpengaruh terhadap kesuksesan SIAKAD [9].

Ada beberapa metode yang dapat digunakan untuk mengevaluasi penerapan sistem informasi akademik dalam institusi pendidikan. Dalam penelitan ini akan dilakukan evaluasi SIAKAD PNM yang dilihat dari sisi pengguna akhir, terkait dengan tingkat penerimaan dan kepuasan pengguna. Tingkat penerimaan pengguna terhadap sistem akan diuji dengan merode TAM dengan variabel kemanfaatan dan kemudahan SIAKAD tersebut, sedangkan tingkat kepuasan pengguna akan diuji dengan meodel EUCS. Perbedaan antara hasil penelitian sebelumnya dengan penelitian yang akan dilakukan, diantaranya berkaitan dengan metode yang digunakan, inovasi, serta kompleksitas permasalahan yang diajukan, selain itu perbedaan terhadap objek penelitian.

\section{METODE PENELITIAN}

Penelitian ini merupakan penelitian deskriptif kuantitatif. Penelitian deskriptif adalah penelitian yang menggambarkan karakteristik dari suatu keadaan objek yang diteliti. Analisis deskriptif digunakan untuk memberikan gambaran tentang data yang telah diperoleh. Analisis kuantitatif adalah penelitian yang di gunakan untuk meneliti populasi atau sampel tertentu yang representatif, pengumpulan data lapangan dengan menggunakan kuesioner, analisis data bersifat kuantitatif menggunakan statistik. Model kuisioner bersifat terbuka. Kuesioner diajukan dengan menggunakan skala Likert, meliputi angka 1 sampai dengan 5. Urutan untuk skala ini menggunakan 5 angka penelitian Dalam penelitian ini digunakan model TAM untuk mengetahui tingkat persepsi penerimaan pengguna SIAKAD PNM, sedangkan metode EUCS digunakan untuk mengetahui tingkat kepuasan pengguna SIAKAD PNM.

Pendekatan model Technology Acceptance Model (TAM) merupakan salah satu model yang paling banyak digunakan dalam penelitian karena model ini lebih sederhana dan mudah diterapkan [10]. TAM dikembangkan untuk menjelaskan perilaku penggunaan komputer. Model ini menempatkan faktor sikap dan tiap-tiap perilaku pemakai dengan dua variabel yaitu kemanfaatan (usefulness) dan kemudahan penggunaan (ease of use). Model EUCS digunakan mengukur kepuasan pemakai terhadap sistem informasi. Sistem informasi suatu organisasi dapat diandalkan apabila memiliki kualitas yang baik dan mampu memberikan kepuasan pada pemakainya. Definisi End User Computing Satisfaction dari sebuah sistem informasi adalah evaluasi secara keseluruhan dari para pengguna sistem informasi yang berdasarkan pengalaman mereka dalam menggunakan sistem tersebut [11]. Dengan adanya kepuasan pemakai tersebut maka akan timbul penerimaan (acceptance) pada sistem informasi yang dipergunakan dalam organisasi tersebut. Kepuasan pemakai (user satisfaction) merupakan salah satu indikator dari keberhasilan pengembangan sistem informasi. Doll dan Torkzadeh mengembangkan instrumen EUCS yang meliputi 5 komponen yaitu terdiri dari: Isi (content), Akurasi (accuracy), Bentuk 
(format), Kemudahan (ease) dan Ketepatan Waktu (timeliness). Pada Gambar 1 ditunjukan model penelitian yang digunakan. Pada gambar 2 dijelaskan alur penelitian yang digunakan.

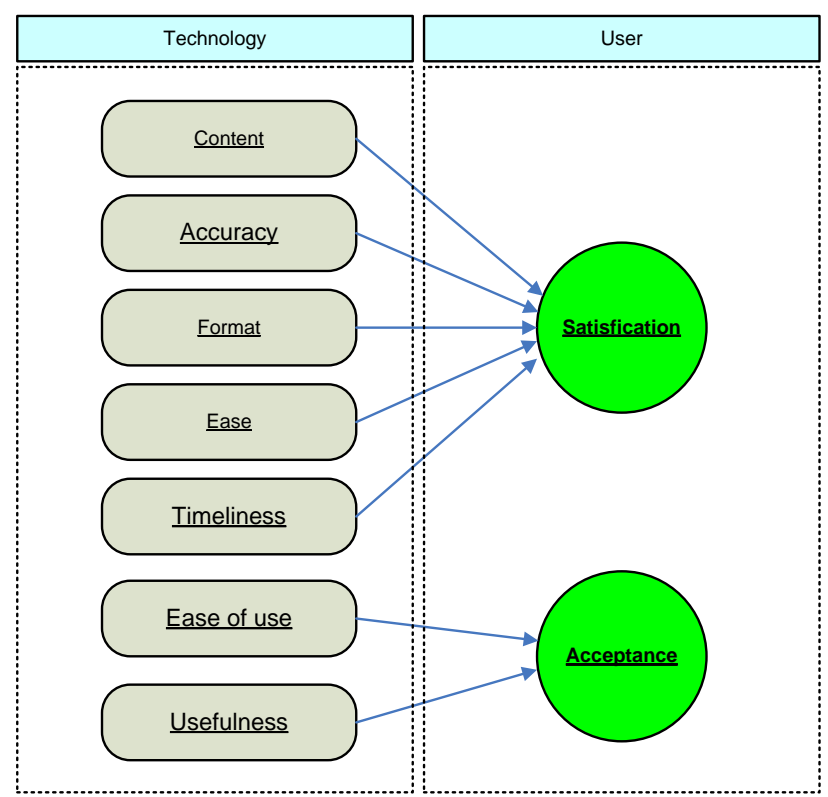

Gambar 1. Model Evaluasi SIAKAD dengan TAM dan EUCS

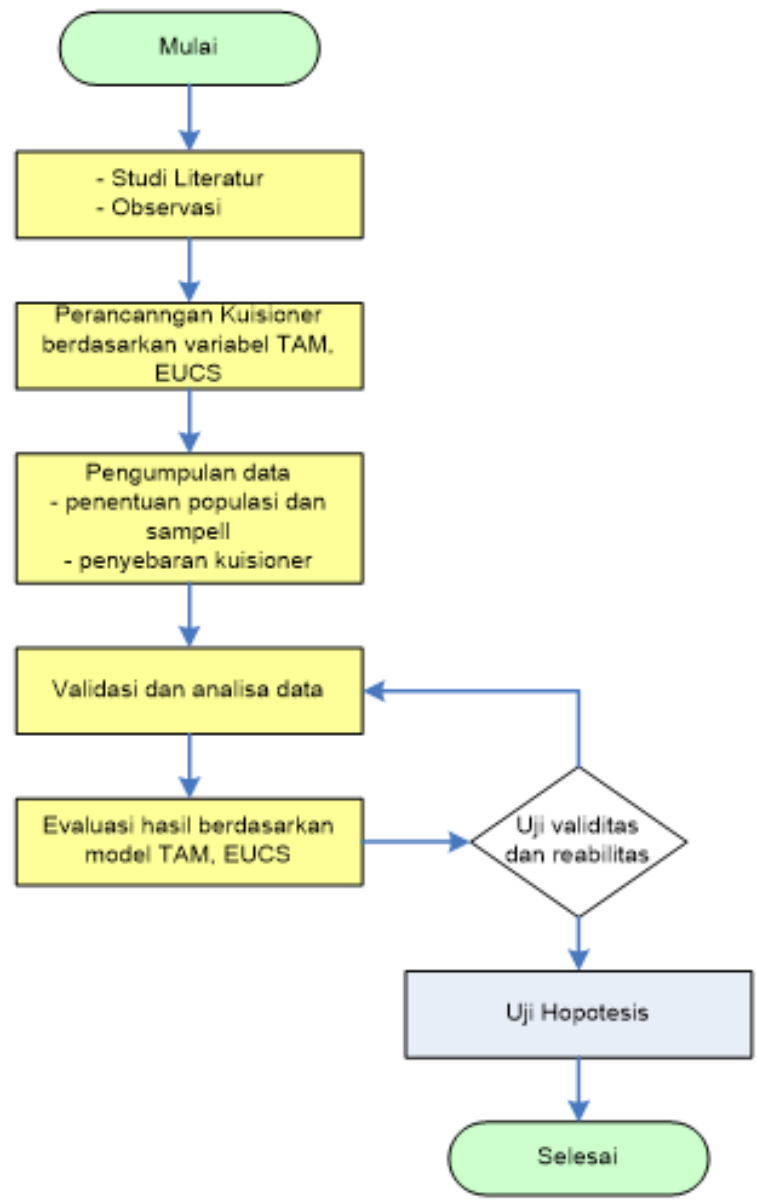

Gambar 2. Alur penelitian 
Data dalam penelitian ini didapatkan dari sampel yang diambil dari populasi pengguna SIAKAD PNM yaitu dari dosen dan mahasiswa semester kedua keatas yaitu data dosen 52 orang dan mahasiswa aktif semester genap 1058 sehingga total responden adalah 1110. Teknik pengambilan sampel menggunakan kuota sampling, yaitu sebanyak 100 responden. Dari 100 kuisioner yang diberikan hanya 96 yang dapat digunakan, karena 1 kuisioner rusak dan 3 tidak kembali.

Pembuatan kuisioner didasarkan pada variabel dan indikator yang ada pada model TAM, seperti dijelaskan pada Tabel 1, (Davies, 1989) serta variabel dan indikator model EUCS, sebagaimana dijelaskan pada Tabel 2. Variabel pada model EUCS digunakan untuk menguji tingkat kepuasan pengguna SIAKAD sedangkan variabel TAM digunakan untuk menguji tingkat penerimaan pengguna terhadap SIAKAD.

Tabel 1. Variabel dan indikator pada model TAM

\begin{tabular}{|c|c|}
\hline Variabel & Indikator \\
\hline $\begin{array}{l}\text { Kemudahan Penggunaan } \\
\text { (Percieved ease of use). }\end{array}$ & $\begin{array}{l}\text { 1) Mudah Untuk digunakan (Ease Of Use ) } \\
\text { 2) Mudah untuk dipelajari (Ease to learn) } \\
\text { 3) Jelas / Mudah dimengerti (Clear/Understandable) }\end{array}$ \\
\hline $\begin{array}{l}\text { Kemanfaatan } \\
\text { (Percieved of Usefulness) }\end{array}$ & $\begin{array}{l}\text { 1) Membuat pekerjaan menjadi lebih cepat (Work More Quickly) } \\
\text { 2) Membuat pekerjaan menjadi lebih mudah (Makes Job Easier) } \\
\text { 3) Menambah Produktivitas (Increase productivity) } \\
\text { 4) Efektif (Effectiveness) } \\
\text { 5) Job Performance }\end{array}$ \\
\hline
\end{tabular}

Tabel 2. Variabel dan Indikator Model EUCS

\begin{tabular}{|l|l|ll|}
\hline & Variabel & & \multicolumn{1}{c|}{ Indikator } \\
\hline 1 & Content & 1) & Tersedia searching untuk pengguna \\
\hline & & 2) & SIAKAD PNM menyediakan informasi yang sesuai dengan kebutuhan \\
\hline & & 3) & Informasi pada SIAKAD menambah pengetahuan saya \\
\hline 2 & Accuracy & 1) & Adanya user id dan pasword untuk setiap user \\
\hline & & 2) & Jarang terjadi error pada sistem \\
\hline & & 3) & Informasi yang diberikan tepat dan benar \\
\hline 3 & Format & 1) & Adanya struktur menu yang teratur \\
\hline & & 2) & Tata letak infromasi dan menu memudahkan navigasi \\
\hline & & 3) & Jenis huruf normal (jelas dan terbaca) \\
\hline 4 & Ease & 1) & Mudah mempelajari/memahami SIAKAD PNM \\
\hline & & 2) & Mudah dalam menelusuri (navigasi)/ berpindah halaman \\
\hline & & 3) & Mudah dalam mengetahui adanya perubahan informasi \\
\hline 4 & Timeliness & 1) & Proses respon time SIAKAD PNM cepat \\
\hline & & 2) & Siakad PNM Memberikan informasi terkini (up to date) \\
\hline & & 1) & Cepat dalam memberikan tanggapan keluhan \\
\hline
\end{tabular}

\section{HASIL DAN PEMBAHASAN}

\subsection{Uji Validitas dan Rehabilitas}

Dalam mengukur aspek yang diteliti diperlukan alat ukur yang valid dan reliable, sehingga kesimpulan dari penelitian tidak menyimpang serta dapat memberikan gambaran yang mendekati keadaan sebenarnya. Uji validitas digunakan untuk mengetahui ke validan kuisioner dalam mengumpulkan data. Pengujian validitas dalam penelitian ini diukur dengan menggunakan 
rumus correlation product moment dengan alat bantu program SPSS versi 21. Rumus correlation product moment sebagaimana ditunjukan pada Persamaan 1.

$$
r_{x y}=\frac{N \sum x y-\left(\sum x\right)\left(\sum y\right)}{\sqrt{\left\{N \sum x^{2}-\left(\sum x\right)^{2}\right\}\left\{N \sum y^{2}-\left(\left(\sum y\right)^{2}\right\}\right.}}
$$

Keterangan :

$r_{x y}=$ Koefisien korelasi product moment

$N=$ Jumlah subjek

$x=$ Skor item

$y=$ Skor total

Hasil dari uji validitas yang dilakukan untuk semua butir pertanyaan dalam penelitian ini dinyatakan valid karena seperti terlihat pada Tabel 3, bahwa nilai $\mathrm{r}_{\text {tabel }}$ lebih kecil dari $\mathrm{r}_{\text {hitung. }}$

Tabel 3. Hasil uji validitas

\begin{tabular}{|c|c|c|c|c|c|}
\hline No & Variabel & $\begin{array}{c}\text { Butir } \\
\text { Pertanyaan }\end{array}$ & $\begin{array}{c}\text { nilai r- } \\
\text { tabel }\end{array}$ & $\begin{array}{c}\text { Koefisien } \\
\text { korelasi }\end{array}$ & Keterangan \\
\hline \multirow{3}{*}{1} & \multirow{3}{*}{$\begin{array}{l}\text { Perceived Usefulness (kemanfaatan) } \\
\mathrm{X} 1\end{array}$} & X1.1 & 0,468 & 0,784 & Valid \\
\hline & & $\mathrm{X} 1.2$ & 0,468 & 0,757 & Valid \\
\hline & & X1.3 & 0,468 & 0,745 & Valid \\
\hline \multirow{3}{*}{2} & \multirow{3}{*}{$\begin{array}{l}\text { Perceived Ease of Use (kemudahan) } \\
\mathrm{X} 2\end{array}$} & $\mathrm{X} 2.1$ & 0,468 & 0,788 & Valid \\
\hline & & $\mathrm{X} 2.2$ & 0,468 & 0,836 & Valid \\
\hline & & X2.3 & 0,468 & 0,801 & Valid \\
\hline \multirow{3}{*}{3} & \multirow{3}{*}{$\begin{array}{l}\text { Content (isi) } \\
\mathrm{X} 3\end{array}$} & X3.1 & 0,468 & 0,871 & Valid \\
\hline & & X3.2 & 0,468 & 0,768 & Valid \\
\hline & & X3.3 & 0,468 & 0,785 & Valid \\
\hline \multirow{3}{*}{4} & \multirow{3}{*}{$\begin{array}{l}\text { Accuracy (akurasi) } \\
\text { X4 }\end{array}$} & $\mathrm{X} 4.1$ & 0,468 & 0,847 & Valid \\
\hline & & $\mathrm{X} 4.2$ & 0,468 & 0,778 & Valid \\
\hline & & $\mathrm{X} 4.3$ & 0,468 & 0,846 & Valid \\
\hline \multirow{3}{*}{5} & \multirow{3}{*}{$\begin{array}{l}\text { Format (bentuk) } \\
\text { X5 }\end{array}$} & X5.1 & 0,468 & 0,806 & Valid \\
\hline & & X5.2 & 0,468 & 0,733 & Valid \\
\hline & & X5.3 & 0,468 & 0,818 & Valid \\
\hline \multirow{3}{*}{6} & \multirow{3}{*}{$\begin{array}{l}\text { Ease (mudah) } \\
\text { X6 }\end{array}$} & X6.1 & 0,468 & 0,756 & Valid \\
\hline & & X6.2 & 0,468 & 0,824 & Valid \\
\hline & & X6.3 & 0,468 & 0,848 & Valid \\
\hline \multirow{3}{*}{7} & \multirow{3}{*}{$\begin{array}{l}\text { Timeliness (ketepatan waktu) } \\
\text { X7 }\end{array}$} & X7.1 & 0,468 & 0,848 & Valid \\
\hline & & X7.2 & 0,468 & 0,787 & Valid \\
\hline & & X7.3 & 0,468 & 0,813 & Valid \\
\hline \multirow{3}{*}{8} & \multirow{3}{*}{$\begin{array}{l}\text { Acceptance } \\
\mathrm{Y} 1\end{array}$} & Y1.1 & 0,468 & 0,867 & Valid \\
\hline & & Y1.2 & 0,468 & 0,72 & Valid \\
\hline & & Y1.3 & 0,468 & 0,848 & Valid \\
\hline \multirow{3}{*}{9} & \multirow{3}{*}{$\begin{array}{l}\text { Satisfaction } \\
\text { Y2 }\end{array}$} & Y2.1 & 0,468 & 0,787 & Valid \\
\hline & & Y2.2 & 0,468 & 0,824 & Valid \\
\hline & & Y2.3 & 0,468 & 0,867 & Valid \\
\hline
\end{tabular}


Citec Journal, Vol. 4, No. 3, Mei 2017 - Juli 2017

ISSN: 2460-4259

Sedangkan uji reliabilitas digunakan rumus Alpa seperti pada Persamaan 2, dinyatakan reliable apabila nilai Cronbach Alpa lebih besar dari $\mathrm{r}_{\text {tabel }}(0,486)$. Persamaan 2 adalah rumus Alpha.

$$
r=\left[\frac{k}{(k-1)}\right]\left[1-\frac{\sum \sigma_{b}^{2}}{\sigma_{t}^{2}}\right]
$$

Keterangan:

$r=$ koefisien instrument reabilitas

$k=$ banyaknya butir pertanyaan

$\sum_{\sigma_{t}^{2}} \sigma_{b}^{2}=$ total varians

Dari hasil pengolahan, bahwa intrumen yang digunakan dalam penelitian ini adalah reliable, sebagaimana ditunjukan pada Tabel 4, diperoleh nilai alpha sebesal 0,968, yang berarti lebih besar dari 0,486.

Tabel 4. Hasil uji reliabilitas

\begin{tabular}{|c|c|c|c|c|c|}
\hline No & Variabel & $\begin{array}{c}\text { Butir } \\
\text { Pertanyaan }\end{array}$ & $\begin{array}{l}\text { nilai r- } \\
\text { tabel }\end{array}$ & Alpha & Keterangan \\
\hline \multirow{3}{*}{1} & \multirow{3}{*}{$\begin{array}{l}\text { Perceived Usefulness (kemanfaatan) } \\
\mathrm{X} 1\end{array}$} & $\mathrm{X} 1.1$ & 0,468 & 0,775 & Reliable \\
\hline & & $\mathrm{X} 1.2$ & 0,468 & 0,749 & Reliable \\
\hline & & $\mathrm{X} 1.3$ & 0,468 & 0,732 & Reliable \\
\hline \multirow{3}{*}{2} & \multirow{3}{*}{$\begin{array}{l}\text { Perceived Ease of Use (kemudahan) } \\
\text { X2 }\end{array}$} & X2.1 & 0,468 & 0,776 & Reliable \\
\hline & & X2.2 & 0,468 & 0,826 & Reliable \\
\hline & & $\mathrm{X} 2.3$ & 0,468 & 0,79 & Reliable \\
\hline \multirow{3}{*}{3} & \multirow{3}{*}{$\begin{array}{l}\text { Content (isi) } \\
\text { X3 }\end{array}$} & X3.1 & 0,468 & 0,866 & Reliable \\
\hline & & X3.2 & 0,468 & 0,759 & Reliable \\
\hline & & X3.3 & 0,468 & 0,775 & Reliable \\
\hline \multirow{3}{*}{4} & \multirow{3}{*}{$\begin{array}{l}\text { Accuracy (akurasi) } \\
\text { X4 }\end{array}$} & $\mathrm{X} 4.1$ & 0,468 & 0,841 & Reliable \\
\hline & & $\mathrm{X} 4.2$ & 0,468 & 0,77 & Reliable \\
\hline & & X4.3 & 0,468 & 0,84 & Reliable \\
\hline \multirow{3}{*}{5} & \multirow{3}{*}{$\begin{array}{l}\text { Format (bentuk) } \\
\text { X5 }\end{array}$} & X5.1 & 0,468 & 0,795 & Reliable \\
\hline & & $\mathrm{X} 5.2$ & 0,468 & 0,72 & Reliable \\
\hline & & $\mathrm{X} 5.3$ & 0,468 & 0,811 & Reliable \\
\hline \multirow{3}{*}{6} & \multirow{3}{*}{$\begin{array}{l}\text { Ease (mudah) } \\
\text { X6 }\end{array}$} & X6.1 & 0,468 & 0,747 & Reliable \\
\hline & & X6.2 & 0,468 & 0,817 & Reliable \\
\hline & & X6.3 & 0,468 & 0,843 & Reliable \\
\hline \multirow{3}{*}{7} & \multirow{3}{*}{$\begin{array}{l}\text { Timeliness (ketepatan waktu) } \\
\text { X7 }\end{array}$} & X7.1 & 0,468 & 0,843 & Reliable \\
\hline & & X7.2 & 0,468 & 0,777 & Reliable \\
\hline & & X7.3 & 0,468 & 0,806 & Reliable \\
\hline \multirow{3}{*}{8} & \multirow{3}{*}{$\begin{array}{l}\text { Acceptance (penerimaan) } \\
\text { Y1 }\end{array}$} & Y1.1 & 0,468 & 0,862 & Reliable \\
\hline & & Y1.2 & 0,468 & 0,711 & Reliable \\
\hline & & Y1.3 & 0,468 & 0,843 & Reliable \\
\hline \multirow{3}{*}{9} & \multirow{3}{*}{$\begin{array}{l}\text { Satisfaction (kepuasan) } \\
\text { Y2 }\end{array}$} & Y2.1 & 0,468 & 0,776 & Reliable \\
\hline & & Y2.2 & 0,468 & 0,816 & Reliable \\
\hline & & Y2.3 & 0,468 & 0,862 & Reliable \\
\hline
\end{tabular}




\subsection{Uji normalitas}

Uji normalitas dilakukan dengan menggunakan uji Kolmogorov-Smirnov, dari uji normalitas tersebut didapatkan nilai signifikansi tiap variabel lebih besar dari $\alpha=0,05$. Sehingga dapat disimpulkan bahwa data terdistribusi normal, data selengkapnya disajikan dalam Tabel 5 berikut.

Tabel 5. Hasil Uji Normalitas dengan One-Sample Kolmogorov-Smirnov

\begin{tabular}{|c|c|c|c|c|c|c|c|c|c|c|}
\hline \multirow{2}{*}{\multicolumn{2}{|c|}{$\mathrm{N}$}} & $\mathrm{x} 1$ & $\mathrm{x} 2$ & y1 & $\mathrm{x} 3$ & $\mathrm{x} 4$ & $\mathrm{x} 5$ & $\mathrm{x} 6$ & $\mathrm{x} 7$ & y2 \\
\hline & & 96 & 96 & 96 & 96 & 96 & 96 & 96 & 96 & 96 \\
\hline \multirow{2}{*}{$\begin{array}{l}\text { Normal } \\
\text { Parameters }\end{array}$} & Mean & 74.4443 & 80.4856 & 75.4864 & 80.9723 & 76.0422 & 77.8485 & 67.6378 & 72.4315 & 78.3342 \\
\hline & Std. Dev. & 11.63556 & 12.1674 & 8.34931 & 9.42668 & 8.12675 & 10.70545 & 10.00531 & 12.56124 & 7.97696 \\
\hline \multirow{3}{*}{$\begin{array}{l}\text { Most } \\
\text { Extreme } \\
\text { Differences }\end{array}$} & Absolute & .163 & .157 & .164 & .217 & .270 & .212 & .236 & .185 & .175 \\
\hline & Positive & .105 & .120 & .164 & .187 & .146 & .196 & .236 & .156 & .151 \\
\hline & Negative & -.163 & -.157 & -.143 & -.217 & -.270 & -.212 & -.205 & -.185 & -.175 \\
\hline \multicolumn{2}{|c|}{ Kolmogorov-Smirnov Z } & 1.594 & 1.534 & 1.611 & 2.124 & 2.647 & 2.074 & 2.310 & 1.812 & 1.714 \\
\hline \multicolumn{2}{|c|}{ Asymp. Sig. (2-tailed) } & .012 & .018 & .011 & .000 & .000 & .000 & .000 & .003 & .006 \\
\hline
\end{tabular}

\subsection{Uji Hipotesa dengan Regresi Berganda}

Setelah instrumen penelitian dinyatakan valid dan reliable tahap selanjutnya adalah dilakukan uji hipotesa. Pengujian ini dilakukan untuk melihat pengaruh variabel bebas terhadap variabel terikat. Pertama, uji Regresi dilakukan untuk melihat pengaruh persepsi ease of use (X1), percived usefulness(X2) terhadap penerimaan pengguna atau acceptance (Y1). Kedua, adalah uji regresi untuk mengukur tingkat kepuasan pengguna yaitu variabel content(X3), accuracy(X4), format(X5), ease(X6) dan timelines(X7) terhadap kepuasan pengguna atau satisfaction(Y2). Pengujian hipotesis dilakukan dengan uji signifikansi simultan dan uji signifikansi parameter individual.

\subsection{1. $\quad$ Uji Variabel X1 dan X2 terhadap Y1}

Berdasarkan uji regresi yang pertama yaitu X1 dan X2 terhadap Y1 didapatkan hasil dengan menggunakan SPSS sebagaimana ditunjukan pada Tabel 6. Secara simultan variabel X1 dan X2 memiliki kontribusi (R Square) sebesar 56,8\% berpengaruh signifikan terhadap variabel Y1 sedangkan sisanya sebesar 43,2\% dijelaskan oleh variabel lain di luar model.

Tabel 6. Hasil uji regresi (X1, X2 terhadap Y1)

\begin{tabular}{|l|l|l|l|c|}
\hline Model & \multicolumn{1}{|c|}{$\mathrm{R}$} & \multicolumn{1}{|c|}{ R Square } & Adjusted R Square & $\begin{array}{c}\text { Std. Error of the } \\
\text { Estimate }\end{array}$ \\
\hline 1 & $.753^{\mathrm{a}}$ & .568 & .558 & 5.54796 \\
\hline
\end{tabular}

Pada bagian uji F sebagaimana terlihat pada Tabel 7, bahwa secara simultan variabelvariabel bebas yaitu X1dan X2 memiliki pengaruh yang signifikan terhadap variabel terikat yaitu Y1 yang ditunjukkan dari nilai Sig. 0,000 < Alpha 5\%. Artinya bahwa H0 ditolak sedangkan H1 dan $\mathrm{H} 2$ diterima atau uji statistik F sudah signifikan). 
Citec Journal, Vol. 4, No. 3, Mei 2017 - Juli 2017

Tabel 7. Hasil Uji F (X1, X2 terhadap Y1)

\begin{tabular}{|c|c|c|c|c|c|c|}
\hline \multicolumn{2}{|c|}{ Model } & $\begin{array}{l}\text { Sum of } \\
\text { Squares }\end{array}$ & $\mathrm{df}$ & $\begin{array}{c}\text { Mean } \\
\text { Square }\end{array}$ & $\mathrm{F}$ & Sig. \\
\hline \multirow[t]{3}{*}{1} & Regression & 3760.019 & 2 & 1880.009 & 61.079 & $.000^{\mathrm{a}}$ \\
\hline & Residual & 2862.530 & 93 & 30.780 & & \\
\hline & Total & 6622.548 & 95 & & & \\
\hline
\end{tabular}

Pada hasil uji T/parsial sebagaimana ditunjukan pada Tabel 8, bahwa variabel X1 dan X2 secara statistik memiliki pengaruh yang signifikan terhadap variabel Y1 yang ditunjukkan oleh nilai Sig masing-masing lebih kecil dari Alpha 5\% yaitu 0,000. Detail ditunjukan dalam tabel 8.

\subsubsection{Uji variabel $X 3, X 4, X 5, X 6$ dan $X 7$ terhadap $Y 2$}

Uji regresi kedua dilakukan untuk variabel bebas X3, X4, X5, X6 dan X7 terhadap variabel terikat Y2. Secara simultan variabel X3, X4, X5, X6 dan X7 memiliki kontribusi (R Square) sebesar $64,5 \%$ berpengaruh signifikan terhadap variabel Y2 sedangkan sisanya sebesar 35,5\% dijelaskan oleh variabel lain di luar model. Hasil uji regresi dengan SPSS selengkapnya dijelaskan pada Tabel 9.

Tabel 9. Hasil uji regresi (X3, X4, X5, X6, X7 terhadap Y2

\begin{tabular}{|l|l|l|l|c|}
\hline Model & $\mathrm{R}$ & $\mathrm{R}$ Square & $\begin{array}{c}\text { Adjusted } \mathrm{R} \\
\text { Square }\end{array}$ & $\begin{array}{c}\text { Std. Error of the } \\
\text { Estimate }\end{array}$ \\
\hline 1 & $.803^{\mathrm{a}}$ & .645 & .625 & 4.88380 \\
\hline
\end{tabular}

a. Predictors: (Constant), x7, x4, x5, x3, x6

Pada uji F seperti ditunjukkan pada Tabel 10, terlihat bahwa secara simultan variabelvariabel bebas yaitu X3, X4, X5, X6 dan X7 memiliki pengaruh yang signifikan terhadap variabel terikat yaitu Y2 yang ditunjukkan dari nilai Sig. 0,000 < Alpha 5\%. Artinya bahwa H0 ditolak sedangkan H3, H4, H5, H6 dan H7 diterima atau uji statistik F sudah signifikan.

Tabel 10. Hasil Uji F (X3, X4, X5, X6, X7 terhadap Y2)

\begin{tabular}{|l|l|r|r|r|r|c|}
\hline \multicolumn{2}{|l|}{ Model } & $\begin{array}{c}\text { Sum of } \\
\text { Squares }\end{array}$ & \multicolumn{1}{c|}{ df } & $\begin{array}{c}\text { Mean } \\
\text { Square }\end{array}$ & $\mathrm{F}$ & Sig. \\
\hline \multirow{3}{*}{1} & Regression & 3898.387 & 5 & 779.677 & 32.689 & $.000^{\mathrm{a}}$ \\
\cline { 2 - 7 } & Residual & 2146.636 & 90 & 23.852 & & \\
\cline { 2 - 7 } & Total & 6045.023 & 95 & & & \\
\hline
\end{tabular}

Pada hasil uji t/parsial sebagaimana ditunjukan pada Tabel 11, bahwa variabel X3 dan X6 secara statistik memiliki pengaruh yang signifikan terhadap variabel Y2, yang ditunjukkan oleh nilai Sig masing-masing lebih kecil dari Alpha 5\% yaitu X3=0,000 dan X6=0,002. Sedangkan $\mathrm{X} 4$, X5 dan X7 tidak berpengaruh positif terhadap Y2 yang ditunjukkan oleh nilai Sig masingmasing lebih besar dari Alpha 5\% yaitu X4 = 0,378, X5=0,692 dan X7=0,878. 
Tabel 11. Hasil uji T (X3, X4, X5, X6, X7 terhadap Y2)

\begin{tabular}{|c|c|c|c|c|c|c|}
\hline \multirow{2}{*}{\multicolumn{2}{|c|}{ Model }} & \multicolumn{2}{|c|}{ Unstandardized Coefficients } & \multirow{2}{*}{$\begin{array}{c}\text { Standardized } \\
\text { Coefficients } \\
\text { Beta }\end{array}$} & \multirow{2}{*}{$\mathrm{t}$} & \multirow[t]{2}{*}{ Sig. } \\
\hline & & B & Std. Error & & & \\
\hline \multirow[t]{6}{*}{1} & (Constant) & 23.620 & 5.184 & & 4.556 & .000 \\
\hline & $\mathrm{x} 3$ & .342 & .087 & .404 & 3.928 & .000 \\
\hline & $\mathrm{x} 4$ & .071 & .080 & .073 & .885 & .378 \\
\hline & $\mathrm{x} 5$ & -.037 & .093 & -.050 & -.397 & .692 \\
\hline & $\mathrm{x6}$ & .350 & .112 & .439 & 3.117 & .002 \\
\hline & $\mathrm{x} 7$ & .011 & .070 & .017 & .153 & .878 \\
\hline
\end{tabular}

\subsection{Pembahasan}

1. Hipotesis 1. Ease of use berpengaruh secara positif terhadap penerimaan penggunaan (acceptance) SIAKAD. Berdasarkan hasil analisis data diperoleh nilai t hitung $(4,749)$ dan sig. $(0,000)$ kurang dari 0,05. Data tersebut menunjukkan bahwa H1 diterima sehingga dapat disimpulkan kemudahan pengguna berpengaruh secara positif terhadap penerimaan pengguna SIAKAD. Hasil tersebut sejalan dengan hasil penelitian Wulan (2017), dimana aspek kemudahan menjadi kunci keberhasilan penerapan teknologi informasi yang digambarkan dengan tingkat penerimaan pengguna akhir terhadap sistem tersebut.[6]. Selanjutnya berdasarkan hasil penelitian Hamrul et.al. (2013) diperoleh kesuksesan penerimaan SIAKAD dapat dijelaskan dengan baik oleh konstruk perceived ease of use pada metode TAM. Oleh karena itu, dalam suatu system perlu diperhatikan kemudahan dalam penggunaan sistem tersebut. Pada hakikatnya sistem dikembangkan untuk memudahkan pengguna untuk melakukan suatu pekerjaan, sehingga jika system itu membuat penggunanya kesulitan dalam menggunakan atau mengoperasikan maka bisa dikatakan bahwa system tersebut tidak berhasil. Dari uraian diatas dapat disimpulkan bahwa kemudahan pengguna berpengaruh secara positif terhadap penerimaan pengguna SIAKAD.

2. Hipotesis 2. Usefulness berpengaruh secara positif terhadap penerimaan penggunaan SIAKAD. Dari hasil analisis data diperoleh nilai thitung $(6,755)$ dan sig. $(0,000)$ kurang dari 0,05. Data tersebut menunjukkan bahwa H2 diterima sehingga dapat disimpulkan bahwa kemanfaatan pengguna berpengaruh secara positif terhadap penerimaan pengguna SIAKAD. Menurut hasil penelitian Wulan (2017) dimana aspek kemanfaatan menjadi kunci keberhasilan penerapan teknologi informasi yang digambarkan dengan tingkat penerimaan pengguna akhir terhadap sistem tersebut adalah manfaat pengguna. Manfaat merupakan salah satu faktor yang juga perlu menjadi bahan pertimbangan sebelum membuat suatu sistem misalnya adalah SIAKAD.[6]. SIAKAD merupakan kumpulan dari sub-sistem yang saling berkaitan satu sama lain dan bekerja sama secara harmonis untuk mengolah data menjadi informasi yang dibutuhkan oleh pengguna dalam kegiatan akademik [12]. Hal ini menjadi pertimbangan seberapa besar manfaat yang dihasilkan dari sistem SIAKAD kepada penggunanya, sehingga pengguna dapat memperoleh manfaat dari sistem tersebut. Berdasarkan uraian tersebut dapat disimpulkan bahwa kemanfaatan pengguna berpengaruh secara positif terhadap penerimaan pengguna SIAKAD

3. Hipotesis 3. Content berpengaruh secara positif terhadap kepuasan penggunaan SIAKAD. Dari hasil analisis data diperoleh nilai t hitung $(3,928)$ dan sig. $(0,000)$ kurang dari 0,05 . Data tersebut menunjukkan bahwa H3 diterima sehingga dapat disimpulkan bahwa content berpengaruh secara positif terhadap kepuasan penggunaan SIAKAD.

4. Hipotesis 4. Accuracy berpengaruh secara positif terhadap kepuasan penggunaan SIAKAD. Berdasarkan hasil analisis data diperoleh nilai t hitung $(0,885)$ dan sig. $(0,378)$ lebih dari 0,05 . Data tersebut menunjukkan bahwa H4 ditolak, sehingga dapat disimpulkan bahwa accuracy tidak terdapat pengaruh secara positif terhadap kepuasan penggunaan SIAKAD 
5. Hipotesis 5. Format berpengaruh secara positif terhadap kepuasan penggunaan SIAKAD. Berdasarkan hasil analisis data diperoleh nilai t hitung $(-0,397)$ dan sig. $(0,692)$ lebih dari 0,05. Data tersebut menunjukkan bahwa H5 ditolak, sehingga dapat disimpulkan bahwa Format tidak terdapat pengaruh secara positif terhadap kepuasan penggunaan SIAKAD

6. Hipotesis 6. Ease berpengaruh secara positif terhadap kepuasan penggunaan SIAKAD. Berdasarkan hasil analisis data diperoleh nilai t hitung $(3,117)$ dan sig. $(0,02)$ kurang dari 0,05. Data tersebut menunjukkan bahwa maka H6 diterima, sehingga dapat disimpulkan bahwa ease berpengaruh secara positif terhadap kepuasan penggunaan SIAKAD

7. Hipotesis 7. Timeliness berpengaruh secara positif terhadap kepuasan penggunaan SIAKAD. Berdasarkan hasil analisis data diperoleh nilai t hitung $(0,153)$ dan sig. $(0,878)$ lebih dari 0,05. Data tersebut menunjukkan bahwa H7 ditolak, sehingga dapat disimpulkan bahwa timeliness tidak terdapat pengaruh secara positif terhadap kepuasan penggunaan SIAKAD.

\section{KESIMPULAN}

Dari hasil penelitian dan pembahasan diatas dapat ditarik kesimpulan sebagai berikut

1. Secara keseluruhan SIAKAD PNM dapat diterima pengguna dengan baik yang dibuktikan dengan model TAM dengan variabel ease of use (X1) dan usefulness (X2) terhadap variabel Acceptance (Y1) baik secara simultan maupun parsial.

2. Pengguna merasa puas terhadap SIAKAD, yang diukur melalui variabel EUCS yaitu Content (X3), Accuracy (X4), Format (X5), Ease (X6) dan Timelines (X7) terhadap user Satisfaction (Y2) secara simultan, akan tetapi secara parsial hanya variabel content (X3), dan ease (X6) yang berpengaruh positif terhadap kepuasan (Y2), sedangkan variabel Accuracy (X4), Format (X5) dan Timelines (X7) tidak berpengaruh positif terhadap kepuasan (Y2).

3. Perlu dilakukan pengkajian lebih lanjut untuk mengetahui faktor-faktor yang mempengaruhi variabel accuracy, format, dan timelines pada SIAKAD tidak berpengaruh positif secara parsial terhadap kepuasan pengguna SIAKAD PNM.

4. Model evaluasi TAM dan EUCS dalam penelitian ini hanya sebatas pada sisi pengguna teknologi, untuk dapat mengetahui tingkat kesuksesan penerapan sistem informasi harus dilakukan evaluasi terhadap internal manajemen sistem yang meliputi sumber daya internal SIAKAD.

\section{SARAN}

Saran untuk penelitian selanjutnya adalah sebagai berikut:

1. Perlu dilakukan evaluasi dengan menggunakan atau membandingkan dengan model lain dan atau penggabungan beberapa model sehingga hasil yang didapatkan lebih akurat dan valid.

2. Penelitian ini hanya mengevaluasi siakad dari sisi pengguna (frontend), kedepan dapat dilakukan penelitian yang menggabungkan evaluasi dari sisi pengguna dan pengelola SIAKAD (backend) seperti masalah manejemen kualitas, manajemen keamanan, service request and incidents, penanganan permasalahan, penanganan security service.

3. Penelitian selanjutnya dapat ditambahkan variabel pengujian terhadap SIAKAD seperti, performance, sistem reliability, efficiency untuk meningkatkan kepuasan pengguna.

4. Kedepan perlu digunakan lingkup populasi yang lebih luas (menambahkan staff dan karyawan sebagai responden) untuk mendapatkan data yang lebih akurat.

5. Hasil dari penelitian ini dapat dijadikan tolak ukur dalam perbaikan dan pengembangan SIAKAD PNM kedepan agar lebih baik lagi. 


\section{DAFTAR PUSTAKA}

[1] Hammer, M., Champy, J., 2010, Reengineering the Corporation: A Manifesto for Business Revolution, Harper Business, New York.

[2] Terziovski, M., 2009, Energizing Management throught Innovation and Intrepreneurship, Rouledge, Oxford.

[3] Prihantara, A., Winarno, W. W., Henderi., 2015, Evaluasi Implementasi Sistem Informasi Kemahasiswaan di STKIP PGRI Pacitan, Jurnal Sisfotenika, No. 1, Vol. 5, Hal 71-81

[4] Arifah, F, N., Rosid, A., Al Fatta, H., 2014, Evaluasi Kepuasan Pelayanan Pengguna Aplikasi OPAC Perpustakaan STMIK AMIKOM Yogyakarta, Creative Information Technology Journal (CITEC Journal), No. 1, Vol. 1, Hal 46-56.

[5] Nursyanti, R., Erlangga., 2013, The Evaluation of Information System Performance in Higher Education Case Study with EUCS Model at Bandar Lampung University, $2^{\text {nd }}$ International Conference on Engineering and Technology Development (ICETD) 2013, Bandar Lmapung, 27-29 Agustus.

[6] Wulan, B. A., Soedijono, B. WA., Henderi., 2017, Evaluasi Penerimaan Bio Sistem Online Menggunakan Pendekatan Technology Acceptance Model (TAM), Jurnal Teknologi Informasi, No. 34, Vol. 12, Hal. 26-35

[7] Safitri, L., 2013, Pengukuran penerimaan teknologi virtual class pada mahasiswa dengan menggunakan metode TAM dan Webqual, Jurnal Elektronik, No. 11, Vol. 7, Hal. 09-14

[8] Feoh, G., Linawati., Wirastuti, N. M. A. E. D., 2015, Indeks Kepuasan Pengguna Situs Web E-Gov Di Bali Dengan Metode EUCS Dan CSI, Konferensi Nasional Sistem \& Informatika, STMIK STIKOM Bali, Bali, 9-10 Oktober.

[9] Uska, M, Z., Dantes, G.R., Candiasa, M., 2016, Evaluasi Implementasi Kesuksesan Sistem Informasi Akademik (SIAKAD) Menggunakan ERP Success Model (Studi Kasus STKIP Hamzanwadi Selong), e-Journal Program Pascasarjana Universitas Pendidikan Ganesha, Vol 1.

[10] Igbaria, M., 1994, An Examination of the factors contributing to Microcomputer Technology Acceptance, Accounting, Management and Information Technologies, No. 4, Vol. 4, Hal. 205-224.

[11] Doll, W.J., Torkzadeh, G., 1988, The Measurement of End-User Computing Satisfaction: Theoretical Considerations, MIS Quarterly, No. 2, Vol. 12, Hal. 259-274.

[12] Sutabri, T., 2012, Analisis Sistem Informasi, Ed.1, Andi Publisher, Yogyakarta. 